Article

\title{
Treatment of Wastewater Containing Runway De-Icing Agents in Biofilters as a Part of Airport Environment Management System
}

\author{
Joanna Rodziewicz $^{1}$, Artur Mielcarek ${ }^{1, *(\mathbb{D}) \text {, Wojciech Janczukowicz }}{ }^{1}$, Kamil Bryszewski ${ }^{1}$ and $^{1}$ \\ Kamila Ostrowska ${ }^{2}$ \\ 1 Department of Environment Engineering, University of Warmia and Mazury in Olsztyn, \\ Warszawska St. 117a, 10-719 Olsztyn, Poland; joanna.rodziewicz@uwm.edu.pl (J.R.); \\ jawoj@uwm.edu.pl (W.J.); kamil.bryszewski@uwm.edu.pl (K.B.) \\ 2 Visimind Ltd Sp. z o.o., Trylinskiego St.10, 10-683 Olsztyn, Poland; kamila.c.ostrowska@gmail.com \\ * Correspondence: artur.mielcarek@uwm.edu.pl; Tel.: +48-89-5233846
}

Received: 30 March 2020; Accepted: 28 April 2020; Published: 29 April 2020

\begin{abstract}
Large volumes of pavement de-icing and anti-icing fluids, collectively termed de-icing agents, are used at airports to facilitate wintertime safe air travel. After use, most of the them get typically mixed with storm water runoff and may enter soil and waters near the airports. Wastewater resulting from airports' winter operations is contaminated mainly with nitrogen and carbon compounds. Previous research results have shown that the use of biofilters filled with lightweight aggregates prepared from fly ash from sewage sludge thermal treatment (FASST LWA) could be an effective method for removing nitrogen and organic compounds at low temperatures, i.e., $0-8{ }^{\circ} \mathrm{C}$. For this to be possible, it is necessary to maintain a proper ratio between the amounts of carbon and nitrogen in the treated wastewater, through the simultaneous application of de-icing agents containing urea and carbon compounds. Biofilter technology is part of the concept of sustainable development. Their filling is made of waste materials and one of the pollutants (organic compounds) present in the wastewater is used to remove other pollutants (nitrogen compounds). In this study, technological systems for the treatment of wastewater containing airport runway de-icing agents with biofilters were proposed, which allow for the treated wastewater to be discharged into natural waters, soil, and sewerage network.
\end{abstract}

Keywords: airport pavement de-icing agents; contaminated rainwater management; biofilters

\section{Introduction}

Large volumes of pavement de-icing agents are used at airports to facilitate wintertime safe air travel. Chemicals commonly used in this respect include: urea, acetate, and sodium formate in the solid form, as well as acetate and potassium formate in the liquid form [1,2]. After use, most of the de-icing agents get typically mixed with storm water runoff and enter grounds and waters near the airfield pavements. The wastewater resulting from airports' winter operations is contaminated mainly with nitrogen and carbon compounds, while the average total phosphorus levels do not exceed the limit values. Airport runway wastewater is characterized by chemical oxygen demand (COD) of up to $630,000 \mathrm{mg} \mathrm{O} / \mathrm{L}$, total nitrogen concentration from 0 to $600 \mathrm{mg} / \mathrm{L}$, and total phosphorus concentration below $1 \mathrm{mg} / \mathrm{L}$ [2-4]. According to the Environmental Protection Agency, COD and total nitrogen (TN) are indicators of the quality of wastewater containing de-icing agents [5].

Airports strongly affect the natural environment [6]. Apart from domestic sewage [7], a significant problem is posed by wastewater from de-icing airport runway. The nitrogen and carbon compounds 
used in deicing operations are related to a number of adverse environmental and ecological effects, e.g., fertility of water environment, resulting in the accelerated eutrophication of surface waters, formation of oxygen deficits, and loss in both the biodiversity and the economic value of waters, including recreational use. Because of the scale of surface water eutrophication problem, the removal of nitrogen is the priority [8].

The issue of the treatment of wastewater containing de-icing agents remains unresolved [9], which results in the penetration of most of these substances into the ground and water near airports [10]. Most airports are not equipped with a wastewater treatment system. Only a few airports in the world have wetlands [11], which effectively remove pollution from wastewater. However, wetlands create favorable environmental conditions for birds [12], which may endanger airport operations. Other solutions include filters with zeolite and perlite [3], media made of crushed clay and granular activated carbon [1], a mixture of granular activated alumina and porous concrete, granular activated lignite, half-burnt dolomite, and granular ferric hydroxides [13].

Considering sustainable development principles, the best solution would be to use the filling made of waste materials, e.g., light weight aggregates prepared from fly ash from sewage sludge thermal treatment (FASST LWA) [14]. It is characterized by a large specific surface, is resistant to physicochemical factors, exhibits low heat conductivity [15] and good phosphorus-sorption properties [16], and facilitates the deammonification process [17]. These attributes provide good conditions for biofilm growth even at low temperatures [18].

The previous authors' research has shown that the use of biofilters with lightweight aggregates prepared from fly ash from sewage sludge thermal treatment (FASST LWA) filling could be an effective method for removing nitrogen and organic compounds from wastewater containing airfield deicing fluids. The nitrogen compounds were removed as a result of the simultaneous process of nitrification and denitrification, where the organic compounds present in the treated wastewater served as a carbon source [14,19].

Temperature, $\mathrm{C} / \mathrm{N}$ ratio, and the hydraulic loading of biofilter (HL) - these are the factors which influence carbon and nitrogen removal efficiency in biofilters. When designing a sewage treatment plant for airport runway wastewater, it should be borne in mind that the vast area of airports and significant fluctuations in atmospheric precipitation contribute to huge differences in wastewater flows discharged to treatment systems. During exploration at airports, in technical conditions, the volume of de-icing wastewater flowing into the biofilters can change drastically.

The use of FASST LWA granules for airport runway wastewater treatment in biofilters has an additional ecological effect resulting from the management of solid wastes (fly ash from sewage sludge thermal treatment), which is usually stored. Besides, the expected technological effect, i.e., the effective removal of pollutants at low temperatures, requires a specific way of winter airport operation through the simultaneous application of de-icing agents containing urea and easily biodegradable carbon compounds. As a consequence, no additional materials and raw materials are consumed in the treatment process; moreover, the removal of nitrogen in the denitrification process is not associated with the extra cost of purchasing an external carbon source, because one of the pollutants (organic compounds) present in the wastewater is used to remove other pollutants (nitrogen compounds).

The advantages of granulate confirmed in tests on a laboratory scale have led to considerations on the possibility of its application on a technical scale. The synthesis of the results of both cited investigations $[14,19]$ is a part of this paper. Based on the results of laboratory studies, technological systems of wastewater treatment plants for wastewater containing airport runway de-icing agents with the use of biofilters were proposed, which enable the treated wastewater to be discharged into natural waters, soil, and the sewerage network (common, sanitary, storm water sewers). We hope that the results of our study will help engineers responsible for environmental protection at airports and provide a technological solution to treat wastewater containing de-icing agents from airport pavements. 


\section{Polish Regulations Concerning the Quality of Wastewater Discharged from Impervious Surfaces of Airport Areas}

There are no specific provisions in Polish regulations regarding the removal of nitrogen and carbon compounds from wastewater generated upon the use of de-icing agents for airport runways. The current Regulation of the Minister of Maritime Economy and Inland Navigation of 12 July 2019 on the conditions to be met when discharging wastewater into water or into the ground, and on substances particularly harmful to the aquatic environment [20], stipulates general requirements for rainwater and snowmelt discharged from built-up areas, including airports. Pursuant to $\S 21$ of the Regulation, "rainwater and snowmelt discharged to open or closed sewage systems that originate from a contaminated impervious surface of industrial areas, storage areas, transport bases, ports, airports, cities of railway constructions, roads classified as national, voivodship and local roads of class $G$, as well as parking lots with an area of over $0.1 \mathrm{ha}$, in the amount resulting from precipitation with the intensity of at least $15 \mathrm{~L}$ per second per 1 ha ...... released into waters or into the ground should not contain pollutants in quantities exceeding $100 \mathrm{mg} / \mathrm{L}$ of total suspended solids and $15 \mathrm{mg} / \mathrm{L}$ hydrocarbons of petroleum origin". This record necessitates the use of only separators of petroleum-based substances and settling tanks.

Therefore, the need to remove carbon and nitrogen compounds from rainwater and snowmelt from the impervious surfaces of airports is primarily due to the environmental hazards posed by this type of outflow to the natural environment. The severity of these hazards stems from the concentration of nitrogen and carbon compounds in rainwater and snowmelt from airports and from their volume, which is a consequence of the size of airport runways and the frequency of using de-icing agents. It needs to be emphasized that the composition of the wastewater from de-icing airport surfaces is very variable and depends primarily on meteorological phenomena. Secondly, it depends on the anti-freezing and de-icing methods applied, types of chemicals used, and their amounts.

Values of the maximum wastewater concentrations (COD and total Kjeldahl nitrogen: 630,000 mg $\mathrm{O}_{2} / \mathrm{L}$ and $600 \mathrm{mg} / \mathrm{L}$, respectively [4]), prove that when using large doses of de-icing agents, rainwater should not be discharged directly into the storm water drainage system nor to natural receivers. This, obviously, prompts the need to design a 'flexible' rainwater management system at the airport, i.e., the one in which, during the period when de-icing agents are not used, rainwater will be discharged into the storm water drainage system, water, or soil. In turn, after using de-icing agents, rainwater in the form of wastewater should be, where possible, discharged into the sanitary sewage system or the general sewage system of a given city the airport is located in.

The operator of the sewage network at the airport should take into account the provisions of the Regulation of the Minister of Construction of 14 July 2006 on the manner of fulfilling the obligations of industrial suppliers and conditions for introducing sewage to sewage facilities and the Regulation of the Minister of Infrastructure and Development of 23 September 2015 [21,22]. Pursuant to these documents, the water supply and sewage company determines the maximum volume of sewage and acceptable values of pollution indicators in wastewater discharged by the industrial wastewater supplier, based on the balance of quantity and quality of municipal wastewater discharged to wastewater treatment plants, the actual capacity of the treatment plant, and the removal efficiency achieved.

In the case of wastewater from airport de-icing, pollution indicators whose values should be taken into account are COD and ammonia nitrogen. In accordance with the Regulation, the acceptable COD concentration of wastewater from de-icing will be determined on the basis of the permissible load of the wastewater treatment plant with organic compounds expressed as the COD index. In contrast, also pursuant to this Regulation, the maximum concentration of ammonia nitrogen (the prevailing form of nitrogen in de-icing wastewater after the use of urea) should not exceed 100 or $200 \mathrm{mg} \mathrm{N} \mathrm{NH}_{4} / \mathrm{L}$ depending on the population equivalent $(\mathrm{PE})$ of the wastewater treatment plant. Based on the specified allowable wastewater flow and COD concentration in the wastewater supplied to the sewage systems, and the known concentration of this indicator in the wastewater generated when using airport de-icing 
agents, the required removed load can be calculated, which must be achieved in the pretreatment facilities before wastewater is discharged to the sewage systems.

In turn, due to the scale of potential environmental hazards, the Regulation of the Minister of Maritime Economy and Inland Navigation of 12 July 2019 [22] shall apply considering discharge of wastewater from airport de-icing to the natural environment (water or ground). Pursuant to this Regulation, the COD concentration of wastewater discharged to waters or into the ground must not be higher than 150 or $125 \mathrm{mg} \mathrm{O}_{2} / \mathrm{L}$ and the total nitrogen concentration should range from 10 to $40 \mathrm{mg} \mathrm{O}_{2} / \mathrm{L}$ (depending on the type of a receiver and PE of the wastewater treatment plant). The collation of the maximum values of wastewater pollutants discharged from the airport runway and the requirements for treated wastewater indicate the severe threat posed to the natural environment by the use of de-icing agents. In addition, they prove that the current regulations take no account of this hazard.

Airport operators in Europe are also under scrutiny to cope with the regulations focusing on the environmental impacts of de-icing practices. The Water Framework Directive (2000/60/EC) [23] and Soil Directive (2004/35/EC) [24] have put de-icing practices under the microscope. The focus of managing waters containing de-icing chemicals has been put on source reduction, containment, stormwater treatment, and/or safe disposal.

In this case, it is necessary to design a system with a wastewater treatment plant which, according to the authors of this article, would operate based on biofilters filled with lightweight aggregates prepared from fly ash from sewage sludge thermal treatment (FASST LWA). The results of earlier studies $[14,19]$, described below, have proved it to be a very promising technological solution.

\section{Materials and Methods}

\subsection{Experimental Stand and Organization}

The study was performed in biofilters with FASST LWA filling [14]. FASST LWA had the structure of extended-clay aggregate (with a diameter $\mathrm{d}_{60}=8.2 \mathrm{~mm}$ ) that was prepared from fly ash from sewage sludge thermal treatment in the "Dębogórze" Wastewater Treatment Plant in Gdynia (Poland). The granulate was prepared according to the method of mechanical plasticization and fragmentation of the raw material, followed by firing of small balls (average diameter $\mathrm{d}_{60}$ of $8.2 \mathrm{~mm}$ ) in a rotary kiln at $1200^{\circ} \mathrm{C}[16,19,25]$.

It was performed in laboratory scale models of biofilters, and accomplished in two experiments. The technical parameters of the reactor were: surface area $95 \mathrm{~cm}^{2}$ (diameter-11 cm), volume $2500 \mathrm{~cm}^{3}$ (total height $-24 \mathrm{~cm}$ ), and active volume $1552 \mathrm{~cm}^{3}$ (height of filling-19 $\mathrm{cm}$ ). The first experiment was divided into three series differing in organic carbon biofilters loading (Figure 1).

Experiment 1 was performed at a hydraulic loading of $5 \mathrm{~L} / \mathrm{m}^{2} \cdot d$, which facilitated nitrification and a hydraulic retention time of $4 \mathrm{~d}$, which corresponded to 4-day dosing frequency of de-icing agents at airports. In each series, carried out at the same hydraulic retention time, biofilters were operated at 25 , 8,4 , or $0{ }^{\circ} \mathrm{C}$. The reactor operated at the temperature of $25^{\circ} \mathrm{C}$ was the control reactor. The applied filling and properly selected operating parameters of the reactors resulted in effective simultaneous nitrification and denitrification.

The purpose of the second experiment [19] was to determine the effectiveness and stability of contaminants removal processes in the biofilter with a filling made of FASST LWA treating wastewater containing pavement de-icing agents (urea and readily biodegradable organic compounds), assuming that maintaining a proper $\mathrm{C}: \mathrm{N}$ ratio can ensure the effective removal of pollutants at low temperatures, independently from biofilter hydraulic loading.

Experiment 2 (Figure 2) was based on the conclusion of Experiment 1—good efficiency of removing pollutants from wastewater at low temperatures was achieved, both in the case of nitrogen compounds and COD, when the value of $\mathrm{C} / \mathrm{N}$ was equal to $0.5 \mathrm{gC} / \mathrm{gN}$ [14]. 


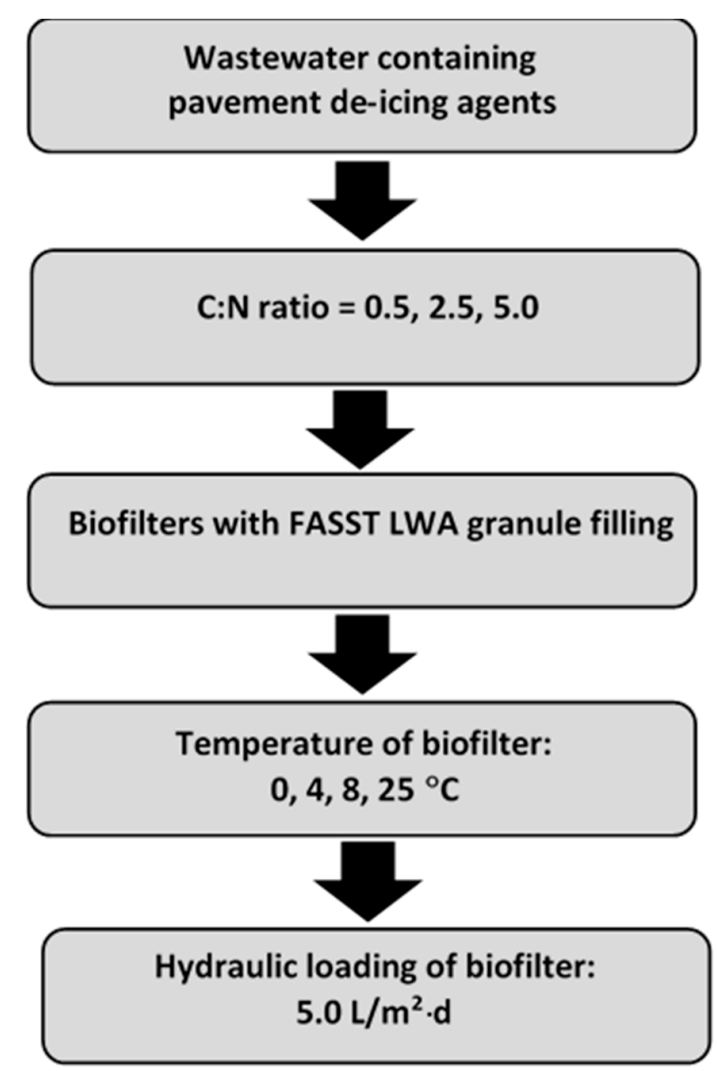

Figure 1. Research scheme of Experiment 1 [14].

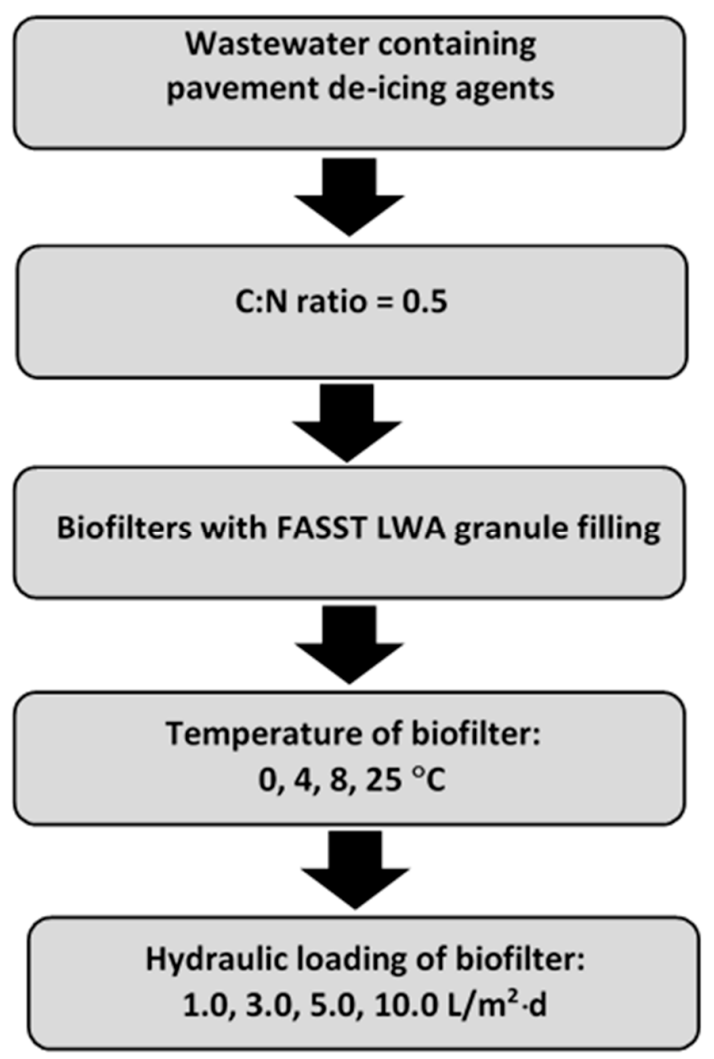

Figure 2. Research scheme of Experiment 2 [19]. 
The goal of the second experiment was to determine the influence of the hydraulic loading on nitrogen and organic compounds (COD) removal depending on the temperature. The experiment was divided into four series differing in the hydraulic loading $\left(1.0,3.0,5.0\right.$, and $\left.10.0 \mathrm{~L} / \mathrm{m}^{2} \cdot \mathrm{d}\right)$. In each series, biofilters were operated at the temperature of $0,4,8$, and $25^{\circ} \mathrm{C}$.

\subsection{Characteristics of Wastewater Used in the Experiments}

Synthetic wastewater, prepared from sample weight, which included commonly used agents for de-icing airport pavements and tap water, was the substrate for the experiments (Table 1).

Table 1. Composition of synthetic wastewater [19].

\begin{tabular}{cc}
\hline Parameter & Value \\
\hline $\mathrm{CH}_{4} \mathrm{~N}_{2} \mathrm{O}[\mathrm{mg} / \mathrm{L}]$ & $150.00 \pm 0.10$ \\
$\mathrm{HCOONa}[\mathrm{mg} / \mathrm{L}]$ & $136.00 \pm 0.10$ \\
$\mathrm{CH}_{3}$ COOK $[\mathrm{mg} / \mathrm{L}]$ & $49.00 \pm 0.10$ \\
\hline
\end{tabular}

Series 1, 2, and 3 of Experiment 1 were carried out at the same hydraulic retention time. The concentration of organic compounds in the wastewater was increased to obtain a higher organic loading in the following biofilters. The indicators of raw wastewater in Experiment 1 are presented in Table 2.

Table 2. Average $( \pm \mathrm{SD})$ concentrations of raw wastewater indicators in the subsequent research series of Experiment 1 [14].

\begin{tabular}{cccc}
\hline Parameter & Series 1 & Series 2 & Series 3 \\
\hline $\mathrm{C} / \mathrm{N}[\mathrm{gC} / \mathrm{gN}]$ & 0.5 & 2.5 & 5.0 \\
$\mathrm{~N}_{\text {tot. }}[\mathrm{mg} \mathrm{N} / \mathrm{L}]$ & & $71.56 \pm 2.20$ & \\
$\mathrm{~N}_{\text {Kjeldahl }}[\mathrm{mg} / \mathrm{L}]$ & & $70.80 \pm 3.02$ & \\
$\mathrm{TOC}[\mathrm{mg} \mathrm{C} / \mathrm{L}]$ & $56.96 \pm 1.98$ & $200.80 \pm 4.79$ & $375.71 \pm 6.97$ \\
$\mathrm{COD}[\mathrm{mg} \mathrm{O} / \mathrm{L}]$ & $100.66 \pm 1.34$ & $386.80 \pm 1.94$ & $765.50 \pm 2.90$ \\
Dissolved oxygen $\left[\mathrm{mg} \mathrm{O}_{2} / \mathrm{L}\right]$ & & $6.64 \pm 0.71$ & \\
Redox potential $[\mathrm{mV}]$ & & $189.33 \pm 12.23$ & \\
$\mathrm{pH}$ & & $7.75 \pm 0.28$ & \\
\hline
\end{tabular}

The organic compounds loading in the series of the first experiment are presented in Table 3.

Table 3. The average $( \pm$ SD) reactor pollutant loading in the subsequent research series of Experiment 1 [14].

\begin{tabular}{cccc}
\hline Parameter & Series 1 & Series 2 & Series 3 \\
\hline $\mathrm{C} / \mathrm{N}[\mathrm{gC} / \mathrm{gN}]$ & 0.5 & 2.5 & 5.0 \\
$\mathrm{~N}_{\text {tot. }}\left[\mathrm{mg} \mathrm{N} / \mathrm{m}^{2} \cdot \mathrm{d}\right]$ & & $357.8 \pm 11.00$ & \\
$\mathrm{~N}_{\text {Kjeldahl }}\left[\mathrm{mg} \mathrm{N} / \mathrm{m}^{2} \cdot \mathrm{d}\right]$ & & $354.00 \pm 15.10$ & \\
$\mathrm{~N}_{\mathrm{NH}}\left[\mathrm{mg} \mathrm{N} / \mathrm{m}^{2} \cdot \mathrm{d}\right]$ & & 0.00 & \\
$\mathrm{COD}\left[\mathrm{mg} \mathrm{O}_{2} / \mathrm{m}^{2} \cdot \mathrm{d}\right]$ & $503.30 \pm 7.19$ & $1934.00 \pm 9.47$ & $3827.50 \pm 14.50$ \\
\hline
\end{tabular}

The indicators of raw wastewater used in the second experiment are presented in Table 4. 
Table 4. Average $( \pm$ SD) concentrations of raw wastewater indicators in Experiment 2 [19].

\begin{tabular}{cc}
\hline Parameter & Value \\
\hline $\mathrm{N}_{\text {tot. }}[\mathrm{mg} \mathrm{N} / \mathrm{L}]$ & $71.56 \pm 2.20$ \\
$\mathrm{~N}_{\text {Kjeldahl }}[\mathrm{mg} / \mathrm{Ll}]$ & $70.80 \pm 3.02$ \\
TOC $[\mathrm{mg} \mathrm{C} / \mathrm{L}]$ & $56.96 \pm 1.98$ \\
$\mathrm{COD}\left[\mathrm{mg} \mathrm{O}_{2} / \mathrm{L}\right]$ & $100.66 \pm 1.34$ \\
Dissolved oxygen $\left[\mathrm{mg} \mathrm{O}_{2} / \mathrm{L}\right]$ & $6.64 \pm 0.71$ \\
Redox potential $[\mathrm{mV}]$ & $189.33 \pm 12.23$ \\
$\mathrm{pH}$ & $7.47-8.03$ \\
\hline
\end{tabular}

The organic compounds and nitrogen loadings in the research series of the second experiment are presented in Table 5.

Table 5. The average $( \pm \mathrm{SD})$ reactor pollutant loading in the subsequent research series of Experiment 2 [19].

\begin{tabular}{ccccc}
\hline Parameter & \multicolumn{4}{c}{ Hydraulic Loading of Biofilters $\left[\mathbf{L} / \mathbf{m}^{\mathbf{2}} \cdot \mathbf{d}\right]$} \\
\cline { 2 - 5 } & $\mathbf{1}$ & $\mathbf{3}$ & $\mathbf{5}$ & $\mathbf{1 0}$ \\
\hline $\mathrm{N}_{\text {tot. }}\left[\mathrm{mg} \mathrm{N} / \mathrm{m}^{2} \cdot \mathrm{d}\right]$ & $71.56 \pm 2.20$ & $214.68 \pm 8.27$ & $350.74 \pm 12.27$ & $696.70 \pm 30.63$ \\
$\mathrm{~N}_{\mathrm{Kjeldahl}\left[\mathrm{mg} \mathrm{N} / \mathrm{m}^{2} \cdot \mathrm{d}\right]}$ & $70.80 \pm 3.02$ & $212.4 \pm 5.11$ & $348.50 \pm 10.11$ & $695.18 \pm 23.51$ \\
$\mathrm{~N}-N H_{4}\left[\mathrm{mg} \mathrm{N}^{2} / \mathrm{m}^{2} \cdot \mathrm{d}\right]$ & 0.00 & 0.00 & 0.00 & 0.00 \\
$\mathrm{COD}\left[\mathrm{mg} \mathrm{O}_{2} / \mathrm{m}^{2} \cdot \mathrm{d}\right]$ & $109.48 \pm 5.00$ & $328.45 \pm 7.51$ & $547.42 \pm 17.01$ & $1094.83 \pm 25.02$ \\
\hline
\end{tabular}

\subsection{Analytical Procedures}

Physicochemical analyses of raw and treated wastewater included: nitrate concentration and nitrite concentration-with the colorimetric method using a VWR UV-3100PC Spectrophotometer (China); ammonium nitrogen and Kjeldahl total nitrogen-with the distillation and titration method using a Buchi SpeedDigester K-436 (Switzerland) and a Buchi KjelFlex K-360 (Switzerland); organic compound concentration (COD) — with the titrimetric method using a laboratory heater Gerhardt KI 16 (Germany) according to APHA (APHA, 2012); concentration of total nitrogen (TN)—with the method of oxidative combustion-chemiluminescence using a Shimadzu Corporation TNM-L analyzer (Japan); and dissolved oxygen, $\mathrm{pH}$, redox potential, and temperature-using a HACH HQ440d multi analyzer (U.S.A.).

\section{Results and Discussion}

The first experiment showed the significant influence of the temperature of biofilter operation and the $\mathrm{C} / \mathrm{N}$ ratio in the wastewater on the efficiency of nitrogen removal from wastewater. The highest efficiency of nitrogen removal at $0{ }^{\circ} \mathrm{C}(34.57 \% \pm 4.54 \%)$ was obtained at the $\mathrm{C} / \mathrm{N}$ ratio of $0.5 \mathrm{gC} / \mathrm{gN}$. Similar tendencies were observed for operation temperatures of 4 and $8{ }^{\circ} \mathrm{C}$. The study results also showed a decrease in the efficiency of nitrogen removal with an increase in the $\mathrm{C} / \mathrm{N}$ ratio at the low temperature of biofilter operation (an opposite tendency was observed in the control reactors). The efficiency of denitrification (the lowest at the temperature of $0{ }^{\circ} \mathrm{C}$ ) increased as the temperature and $\mathrm{C} / \mathrm{N}$ ratio increased in the wastewater (Figure 3 ). 


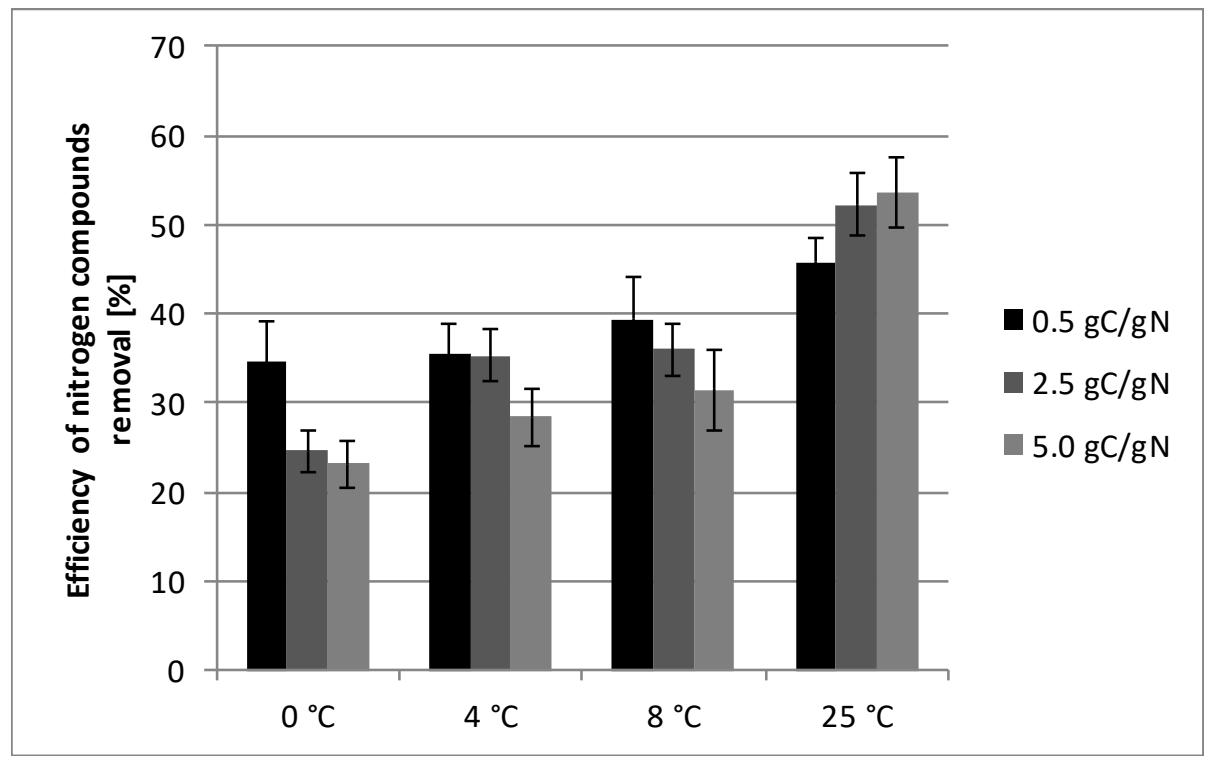

Figure 3. Efficiency of nitrogen compound removal depending on the $\mathrm{C} / \mathrm{N}$ ratio [14].

The study showed that the effective removal of nitrogen compounds in biofilters occurred across a very wide temperature range. FASST LWA filling and properly selected operating parameters of the reactors resulted in the effective nitrification and reduction of oxidized nitrogen forms to gaseous nitrogen. Nitrogen compounds removal was possible due to the simultaneous nitrification and denitrification [26], in which organic compounds contained in the wastewater (in the result of acetate or potassium formate application as de-icing agents) serves as carbon sources. A prerequisite to ensure the effective removal of pollutants at low temperatures is to maintain a proper ratio between the amount of carbon and nitrogen in the treated wastewater, through the simultaneous application of de-icing agents containing urea and easily biodegradable carbon compounds. It is feasible by controlling the amount of de-icing agents, containing urea and simple organic compounds, applied at airports [14].

The second experiment showed that either increasing or decreasing biofilter HL relative to the value of $5.0 \mathrm{~L} / \mathrm{m}^{2} \cdot \mathrm{d}$ contributed to only a negligible decrease in nitrogen removal efficiency (Figure 4).

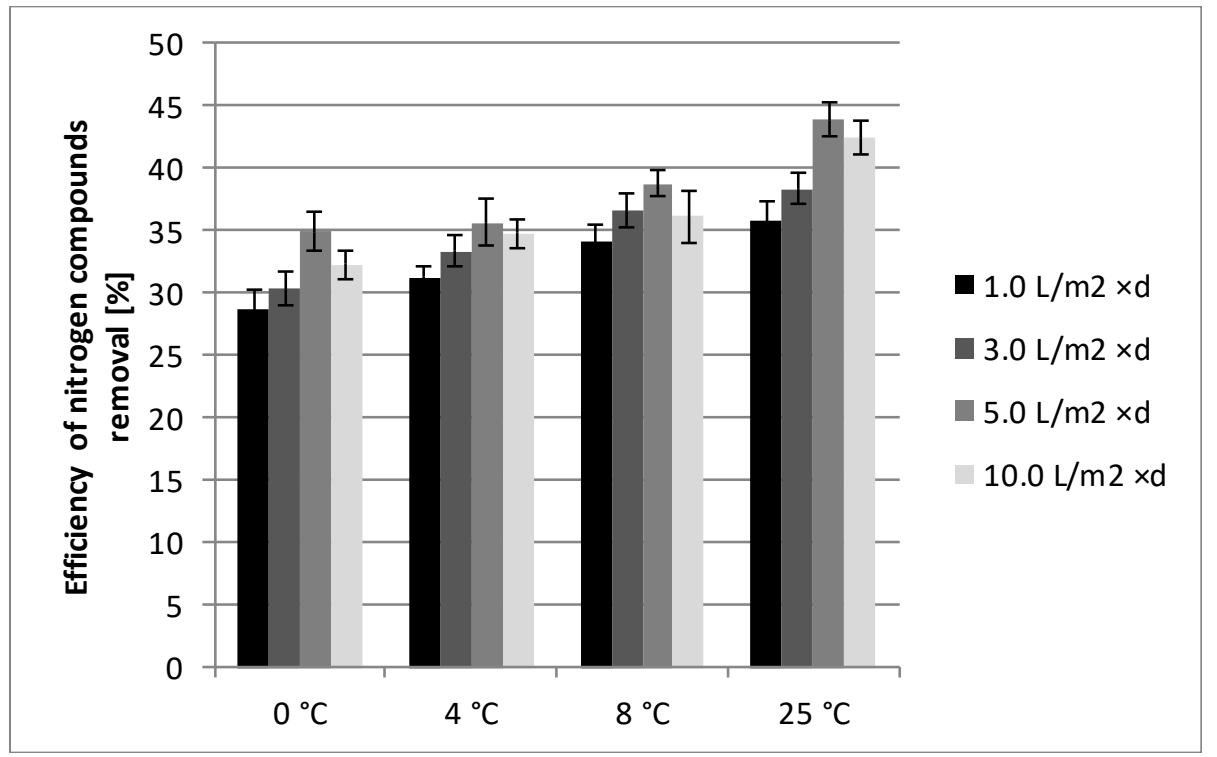

Figure 4. Efficiency of nitrogen compound removal, depending on the hydraulic loading (HL) of biofilters [19]. 
At temperatures tested, an increase in biofilter $\mathrm{HL}$ value from 1.0 to $5.0 \mathrm{~L} \cdot \mathrm{m}^{-2} \cdot \mathrm{d}^{-1}$ caused the increase in the efficiency of nitrogen removal. Whereas, increasing HL to $10.0 \mathrm{~L} \cdot \mathrm{m}^{-2} \cdot \mathrm{d}^{-1}$ caused nitrogen removal efficiency to decrease. An exception was observed for the control biofilter (temperature $25^{\circ} \mathrm{C}$ ) and the biofilter operating at $4{ }^{\circ} \mathrm{C}$, in the case of which the efficiency achieved at $\mathrm{HL} 10.0 \mathrm{~L} \cdot \mathrm{m}^{-2} \cdot \mathrm{d}^{-1} \mathrm{did}$ not change significantly compared to that determined at HL $5.0 \mathrm{~L} \cdot \mathrm{m}^{-2} \cdot \mathrm{d}^{-1}$. These results are consistent with literature data. Nguyen et al. [27] presented similar changes in nitrogen removal efficiency, as affected by hydraulic loading. In addition, Wang et al. [28] failed to demonstrate a linear correlation between nitrogen removal efficiency and HL values (from 0.5 to $3.0 \mathrm{~m}^{3} \cdot \mathrm{m}^{-2} \cdot \mathrm{d}^{-1}$ ). Experiment 2 showed also that the decrease in wastewater treatment efficiency was smaller upon HL increase than upon HL decrease. The research results showed that in the period of intense surface runoffs resulting from more intense atmospheric precipitation and the necessity of using higher amounts of de-icing agents at temperatures of $0-8{ }^{\circ} \mathrm{C}$, it is feasible to increase biofilter HL. It means that there is no risk of compromising the quality of the effluent in respect of nitrogen concentration. Simultaneously, the concentration of organic compounds in treated wastewater will be lower because the increase in HL of the biofilter will boost the efficiency of COD removal [19].

Both experiments have shown that the use of biofilters with FASST LWA filling can be an effective method for removing first of all nitrogen compounds from wastewater containing airfield de-icing fluids. It may be an effective and sustainable method for the removal of nitrogen at low temperatures, i.e., $0-8{ }^{\circ} \mathrm{C}$. What is worth emphasizing is that the nitrogen compounds were removed as a result of the simultaneous process of nitrification and denitrification, where the organic compounds present in the treated wastewater served as a carbon source [14,19].

\section{The Concept of Biofilters Application in Airport De-Icing Wastewater Management System}

The proposed solution will enable the services responsible for winter maintenance of airport surfaces using a wide spectrum of de-icing agents and, at the same time, will ensure a high level of pollutants neutralization. Most airports use de-icing agents based either on simple easy-biodegradable carbon compounds or urea (nitrogen compounds) Not too many airports in the world are equipped with a wastewater treatment system. Technological solutions applied, like aerobic retention ponds, lagoons, fluidized bed biological reactors or wetlands, are not suitable for nitrogen removal. However, they are suitable to remove carbon compounds.

Our technological solution must go hand in hand with a specific way of using de-icing agents. We recommend airport operators the simultaneous use of de-icing agents such as urea and easily-degradable organic compounds, such as acetate or potassium formate, at the airport. This procedure can contribute to the effective nitrification and denitrification processes (consequently to the removal of nitrogen) as well as the effective removal of organic compounds in biofilters with FASST LWA filling. This combination of logistic treatments with a "friendly technology" (characterized by the minimum amount of generated wastewater and by-products) will be an example of a solution inscribing into the idea of sustainable development. One of the pollutants (organic compounds) present in the wastewater will be used to remove other pollutants (nitrogen compounds). In addition, investment costs (airports very often have retention tanks for rainwater and snowmelt) and especially operational costs of the proposed solution will be low, compared to the other biological and physicochemical processes. Easiness of exploitation resulting from uncomplicated operations (mixing wastewater, dosing wastewater to biofilters) as well as technological and technical reliability of the system are also important in its implementation at airports, especially those located far from large population centers and without access to technologically-qualified staff.

When designing the management strategy for rainwater containing de-icing agents, a multi-chamber retention and equalization tank should be provided at the end of the sewage system collecting rainwater and snowmelt from the airport area, whose task will be to equalize wastewater composition and to evenly distribute in time the stream of wastewater supplied to pre-treatment facilities and discharges to the municipal sewage network (Figure 5) [29]. It can be 
expected that, in certain situations, such a tank will provide ammonia nitrogen concentration in the outflow below the permissible values ( 100 or $200 \mathrm{mg} \mathrm{N} \mathrm{NH}_{\mathrm{NH}} / \mathrm{L}$, respectively) due to the equalization of wastewater composition.

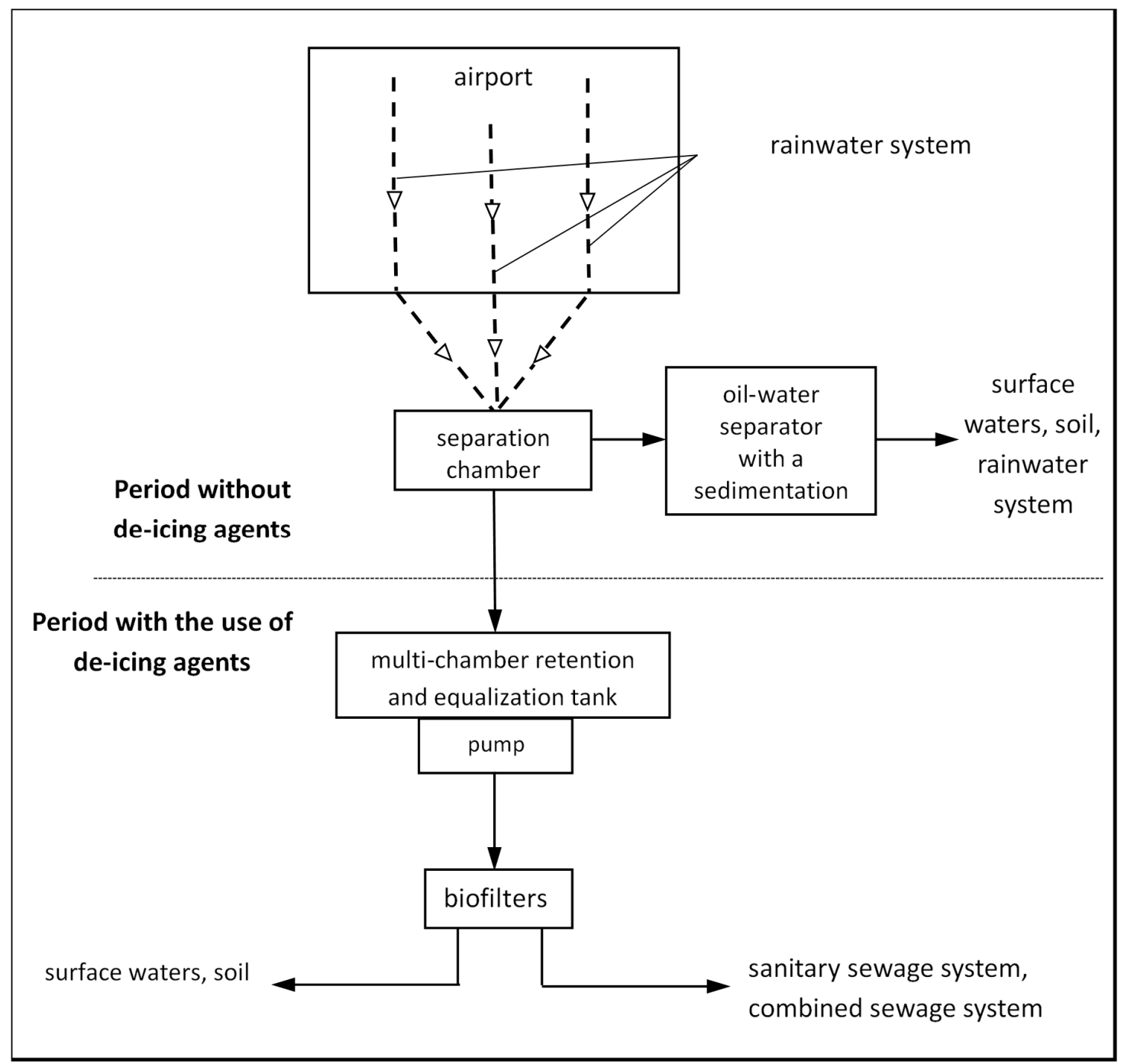

Figure 5. Scheme of a system for managing rainwater and snowmelt water containing de-icing agents from airport surfaces.

Regardless of receiver type (surface water, soil, or sewage system), the technological system of the proposed treatment plant (pre-treatment plant) should consist of a set of biofilters and a pump system enabling the control of the frequency and volume of wastewater doses fed to the biofilters (Figure 3). A single biofilter-a bioreactor in the form of a trickling/flooded filter with vertical wastewater flow-will be equipped with sprinklers responsible for even distribution of wastewater, ensuring the proper loading of biofilter surface with pollutants and the proper hydraulic loading. The sprinkler pump will be run periodically. Wastewater flowing through the bed's filling will undergo a treatment process and then will reach the bottom zone, where under drains and bottom of the biofilter there will be a collecting drainage, which will drain the wastewater to a control well and then to a natural receiver or to the sewage system.

Biofilter surface, frequency of wastewater supply to biofilters, $\mathrm{C} / \mathrm{N}$ value, and wastewater dose will be established based on the surface of areas where de-icing agents are or will be used, their chemical composition, and accepted practices of using such substances resulting, inter alia, from 
meteorological conditions and industry regulations regarding the taxiway and runway maintenance and airport standards. The starting point for adjusting biofilter operating parameters is the assumption that it is possible to effectively remove pollutants from wastewater at low temperatures, with specified parameters of crude wastewater, at a $\mathrm{C} / \mathrm{N}$ ratio of $0.5 \mathrm{gC} / \mathrm{gN}$ [14]. The laboratory investigation results show that the hydraulic loading could be up to $5.0 \mathrm{~L} / \mathrm{m}^{2} \cdot \mathrm{d}$ [19].

The proposed method for the treatment of wastewater generated during airport de-icing, consisting of its treatment in biofilters, is a promising solution for airports located in these climate zones, where their operation at low temperatures depends on the use of de-icing agents. The condition conducive to the effective operation of biofilters in relation to ammonia nitrogen, whose presence in wastewater results from the use of urea as a means for winter maintenance of airport surfaces, is the use of agents containing organic compounds, such as sodium acetate and formate in a solid or liquid form. The inclusion in the wastewater treatment system of a multi-chamber retention and expansion tank equipped with agitators and pumps, enabling sewage to be pumped between chambers, will ensure the possibility of mixing wastewater of varying quality due to the use of various de-icing agents. As a consequence, it will facilitate controlling the composition of wastewater fed to biofilters. The tank should contain chambers for collecting wastewater containing organic compounds, chambers for wastewater generated during the use of urea, chambers for collecting wastewater resulting from the simultaneous use of urea and organic compounds for de-icing, and at least one chamber in which wastewater from individual chambers will be mixed to obtain the appropriate ratio between carbon and nitrogen compounds ( $\mathrm{C} / \mathrm{N}$ ratio).

This system can also be used to treat wastewater from de-icing airport surfaces containing only organic compounds. Those that are commonly used for de-icing are highly biodegradable. They will be removed and used by heterotrophic organisms, but they will not be a source of carbon in the heterotrophic denitrification process, because this process will not take place in the biofilter due to the small amounts of nitrogen in the wastewater being treated. In this situation, it is necessary to equip the chambers not only with agitators but also with aeration devices.

At airports generating wastewater with a lower concentration of pollutants, it is possible to reduce investment costs by using a simplified system-without a retention tank. Then, the construction of ground filters with a subsurface mixed flow of wastewater around airports-directly at the border of concrete surfaces, can be a solution that will allow a further reduction in investment costs due to no need for establishing systems to collect polluted waters and discharging them to the treatment site. The initial vertical flow will allow achieving good conditions for the oxidation of organic matter, because the diffusion of atmospheric oxygen to deeper layers will be high $[3,26]$. Then, the horizontal flow (wastewater retention) will provide conditions appropriate for the denitrification process. Finally, the subsurface flow will prevent development of conditions promoting the nesting of birds, whose presence at airports is undesirable.

\section{Conclusions}

The need for wastewater treatment arising from the use of agents for de-icing airport surfaces is due to the severity of environmental hazards posed by its discharge into surface waters, soil, and ground waters. Based on results of a previous author's research, the treatment system for wastewater was proposed. It consists of a retention and equalization multi-chamber tank equipped with stirrers and aerating devices, a pumping station, and biofilters filled with FASST LWA granulate. It is an example of a 'flexible' rainwater management system, i.e., the one in which, during the period when de-icing agents are not used, rainwater is discharged into the storm water drainage system, water, or soil. In turn, after de-icing agent application, rainwater in the form of wastewater should be, where possible, discharged into the sanitary sewage system or the general sewage system of a city the airport is located in. In the case, when it is necessary to design a system with a wastewater treatment plant, it should operate based on biofilters filled with FASST LWA. The basic assumption for biofilter dimensioning is that it is possible to effectively remove pollutants from wastewater at low temperatures, with specified 
parameters of treated wastewater. A properly equipped (agitators, pumps) multi-chamber retention tank enables sewage to be pumped between chambers and ensures the possibility of mixing wastewater of varying quality due to the use of various de-icing agents. As a consequence, it will facilitate controlling the composition of wastewater fed to biofilters and the contaminant removal efficiency of the final system. This system can be used to treat wastewater from de-icing airport surfaces containing urea and organic compounds or only the last ones.

The treatment of wastewater containing runway de-icing agents in biofilters is an example of good practice in airport environment management.

Author Contributions: Conceptualization, W.J.; Methodology, J.R. and A.M.; Formal Analysis, K.O. and K.B.; Data Curation, A.M.; Writing-Original Draft Preparation, W.J.; Writing-Review \& Editing, J.R Visualization, A.M. and K.B.; Supervision, W.J. All authors have read and approved the final manuscript.

Funding: This research has no external funding.

Acknowledgments: Publication is funded by the Polish National Agency for Academic Exchange under the International Academic Partnerships Programme from the project, Organization of the 9th International Scientific and Technical Conference entitled Environmental Engineering, Photogrammetry, Geoinformatics-Modern Technologies and Development Perspectives" and Project No. 18.610.008-300 of the University of Warmia and Mazury in Olsztyn, Poland.

Conflicts of Interest: The authors declare no conflict of interest.

\section{References}

1. Raspati, G.S.; Lindseth, H.K.H.; Muthanna, T.; Azrague, K. Potential of biofilters for treatment of de-icing chemicals. Water 2018, 10, 620. [CrossRef]

2. Switzenbaum, M.S.; Veltman, S.; Mericas, D.; Wagoner, B.; Schoenberg, T. Best management practices for airport deicing stormwater. Chemosphere 2001, 43, 1051-1062. [CrossRef]

3. Pressl, A.; Pucher, B.; Scharf, B.; Langergraber, G. Treatment of de-icing contaminated surface water runoff along an airport runway using in-situ soil enriched with structural filter materials. Sci. Total Environ. 2019, 660, 321-328. [CrossRef] [PubMed]

4. Shi, X.; Quilty, S.M.; Long, T.; Jayakaran, A.; Fay, L.; Xu, G. Managing airport stormwater containing deicers: Challenges and opportunities. Front. Struct. Civ. Eng. 2017, 11, 35-46. [CrossRef]

5. US EPA. Technical Development Document for the Final Effluent Limitations Guidelines and New Source Performance Standards for the Airport Deicing Category. 2012. Available online: https://www.epa.gov/sites/ production/files/2015-06/documents/airport-deicing-tdd-final-2012.pdf (accessed on 18 May 2019).

6. Kilkiş, Ş.; Kilkiş, Ş. Benchmarking airports based on a sustainability ranking index. J. Clean. Prod. 2016, 130, 248-259. [CrossRef]

7. Corsi, S.R.; Mericas, D.; Bowman, G.T. Oxygen demand of aircraft and airfield pavement deicers and alternative freezing point depressants. Water Air Soil Pollut. 2012, 223, 2447-2461. [CrossRef]

8. Couto, E.D.A.D.; Calijuri, M.L.; Assemany, P.; Santiago, A.; Lopes, L.S. Greywater treatment in airports using anaerobic filter followed by UV disinfection: An efficient and low cost alternative. J. Clean. Prod. 2015, 106, 372-379. [CrossRef]

9. Worrall, P.; Revitt, D.M.; Prickett, G.; Brewer, D. Constructed wetlands for airport runoff-The London Heathrow experience. In Proceedings of the 2nd International Conference on Wetlands \& Remediation, Burlington, VT, USA, 5-6 September 2001.

10. Xie, T.; Dong, J.; Chen, H.; Jiang, Y.; Yao, Y. Experiment investigation on deicing characteristics and energy efficiency using infrared ray as heat source. Energy 2016, 116, 998-1005. [CrossRef]

11. Dou, T.; Troesch, S.; Petitjean, A.; Gábor, P.T.; Esser, D. Wastewater and rainwater management in urban areas: A role for constructed wetlands. Procedia Environ. Sci. 2017, 37, 535-541. [CrossRef]

12. Fox, B.J.; Holland, W.B.; Boyd, F.L.; Blackwell, B.F.; Armstrong, J.B. Use of stormwater impoundments near airports by birds recognized as hazardous to aviation safety. Landsc. Urban Plan. 2013, 119, 64-73. [CrossRef]

13. Huber, M.; Hilbig, H.; Badenberg, S.C.; Fassnacht, J.; Drewes, J.E.; Helmreich, B. Heavy metal removal mechanisms of sorptive filter materials for road runoff treatment and remobilization under de-icing salt applications. Water Res. 2016, 102, 453-463. [CrossRef] [PubMed] 
14. Rodziewicz, J.; Ostrowska, K.; Janczukowicz, W.; Mielcarek, A. Effectiveness of nitrification and denitrification processes in biofilters treating wastewater from de-icing airport runways. Water 2019, 11, 630. [CrossRef]

15. Białowiec, A.; Janczukowicz, W.; Randerson, P. Nitrogen removal from wastewater in vertical flow constructed wetlands containing LWA/gravel layers and reed vegetation. Ecol. Eng. 2011, 37, 897-902. [CrossRef]

16. Białowiec, A.; Janczukowicz, W.; Gusiatin, Z.M.; Thornton, A.; Rodziewicz, J.; Zielinska, M. Recycling potential of air pollution control residue from sewage sludge thermal treatment as artificial lightweight aggregates. Waste Manag. Res. 2014, 32, 221-227. [CrossRef] [PubMed]

17. Rodziewicz, J.; Mielcarek, A.; Janczukowicz, W.; Białowiec, A.; Gotkowska-Płachta, A.; Proniewicz, M.; Joanna, R.; Artur, M.; Wojciech, J.; Andrzej, B.; et al. Ammonia nitrogen transformations in a reactor with aggregate made of sewage sludge combustion fly ash. Water Environ. Res. 2016, 88, 715-723. [CrossRef] [PubMed]

18. Jenssen, P.D.; Mæhlum, T.; Krogstad, T.; Vråle, L. High performance constructed wetlands for cold climates. J. Environ. Sci. Health Part A 2005, 40, 1343-1353. [CrossRef] [PubMed]

19. Rodziewicz, J.; Mielcarek, A.; Janczukowicz, W.; Ostrowska, K.; Jóźwiakowski, K.; Bugajski, P.; Jucherski, A. Biofilter with innovative filling for low-temperature treatment of sewage from de-icing airport runways. Sep. Purif. Technol. 2020, 242, 116761. [CrossRef]

20. Regulation of the Minister of Maritime Economy and Inland Navigation of July 12, 2019 on substances particularly harmful to the aquatic environment and conditions to be met when introducing sewage into waters or into the ground, as well as when discharging rainwater or snowmelt into waters or into water equipment. Dz. U. (J. Laws) 2019, 1311. (In Polish)

21. Regulation of the Minister of Construction of July 14, 2006 on the manner of fulfilling the obligations of industrial suppliers and the conditions for introducing sewage to sewage systems. Dz. U. (J. Laws) 2006, 136, 964. (In Polish)

22. Regulation of the Minister of Infrastructure and Development of September 23, 2015 amending the regulation on the manner of fulfilling the obligations of industrial wastewater suppliers and the conditions for introducing wastewater into sewage systems. Dz. U. (J. Laws) 2015, 1456. (In Polish)

23. Commission of the European Communities. European Parliament, Directive 2000/60/EC of the European Parliament and of the Council Establishing a Framework for Community Action in the Field of Water Policy; Commission of the European Communities: Brussels, Belgium, 2000.

24. Commission of the European Communities. European Parliament, Directive of the European Parliament and of the Council Establishing a Framework for the Protection of Soil and Amending Directive 2004/35/EC; Commission of the European Communities: Brussels, Belgium, 2004.

25. Białowiec, A.; Janczukowicz, W. Granulat z popiołów - właściwości mechaniczne i sorpcyjne. Przeglą Komunaln. 2010, 1, 52-54. (In Polish)

26. Zheng, Z.; Huang, S.; Bian, W.; Liang, D.; Wang, X.; Zhang, K.; Ma, X.; Li, J. Enhanced nitrogen removal of the simultaneous partial nitrification, anammox and denitrification (SNAD) biofilm reactor for treating mainstream wastewater under low dissolved oxygen (DO) concentration. Bioresour. Technol. 2019, 283, 213-220. [CrossRef] [PubMed]

27. Nguyen, X.C.; Chang, S.W.; Nguyen, T.L.; Ngo, H.H.; Kumar, M.D.; Banu, J.R.; Vu, C.M.; Le, H.S.; Nguyen, D.D. A hybrid constructed wetland for organic-material and nutrient removal from sewage: Process performance and multi-kinetic models. J. Environ. Manag. 2018, 222, 378-384. [CrossRef] [PubMed]

28. Wang, H.; Ji, G.; Bai, X. Quantifying nitrogen transformation process rates using nitrogen functional genesin a multimedia biofilter under hydraulic loading rate constraints. Ecol. Eng. 2015, 82, 323-329. [CrossRef]

29. Ostrowska, K. Effectiveness of Wastewater Treatment from De-Icing Airports Pavements in Biofilters. Ph.D. Thesis, Technical University in Lublin, Lublin, Poland, 2018.

(C) 2020 by the authors. Licensee MDPI, Basel, Switzerland. This article is an open access article distributed under the terms and conditions of the Creative Commons Attribution (CC BY) license (http://creativecommons.org/licenses/by/4.0/). 